\title{
Analysis of LQ45 share portfolio on Quadrimester I during the Covid-19 pandemic
}

\author{
Henny Rahyuda ${ }^{a^{*}}$
}

${ }^{a}$ Lecturer, Department of Management, Faculty of Economics and Business, University of Udayana, Bali, Indonesia

\begin{tabular}{l}
\hline C H R O N I C L E \\
\hline Article history: \\
Received March 10, 2021 \\
Received in revised format May \\
102021 \\
Accepted June 102021 \\
Available online \\
June 11 2021 \\
\hline Keywords: \\
Optimal Portfolio \\
Treynor \\
Pandemic
\end{tabular}

\section{A B S T R A C T}

Investment is a way of getting profit by investing a certain amount of capital in certain assets. Investing in shares in LQ45 amid the Covid-19 pandemic is one way to benefit when many sectors are experiencing an economic downturn. The purpose of this study was to analyze the differences in the optimal portfolio of LQ45 stocks in the 2019 and 2020 quadrimester I. The samples of this study were companies listed in LQ45. This research method uses the treynor index and t-test. The results of this study are that there is a significant difference in the optimal portfolio using the treynor index model between quadrimester I 2019 and 2020 on LQ45 stocks, this is influenced by conditions amid the Covid-19 pandemic which affects all sectors. The highest optimal number of purchases in the month April 2020 is occupied by companies with the KLBF code, this is an advantage that the company gets during the Covid-19 pandemic. Future research is expected to be able to allocate investment funds optimally for each share to achieve optimal profits. The investor is expected to be able to estimate in advance the stocks that will be selected for their investment.

\section{Introduction}

Investment is a delay in current consumption for use in efficient production for a certain period (Jogiyanto, 2013). Investment can be defined as an activity to place funds in one or more assets during a certain period with the hope of earning income and / or an increase in investment value (Wiksuana, 2017: 1). An investor buys several shares today in the hope of obtaining a profit from an increase in stock prices or a certain amount of dividends in the future, as a reward for the time of risk associated with the investment (Tandelilin, 2010: 2). Invested assets can be real assets or financial assets (Jogiyanto, 2014: 7). Investments in real assets are in the forms of land, property, and gold, while in financial assets it can be in the form of stocks, bonds, and deposits. The objective of investment is to improve the welfare of investors both in present and in the future (Wiksuana, 2017: 2). According to Tandelilin (2010), there are several reasons people invest, including to get a decent life in the future, reduce inflation, and tax saving purposes. Without the benefits that can be enjoyed from an investment, of course investors will not bother to invest, which at the end will be fruitless. In the investment world, it is known that there is a strong relationship between risk and return, that is, if the risk is high, the return will also be high and vice versa if the return is low, the risk will also be low (Fahmi, 2013; 23). Markowitz in Jogiyanto (2014: 285) explains that to minimize risk and still get a large enough return, we should form a portfolio. A portfolio is a group of securities that have a certain return and risk, where rational investors will choose a portfolio that provides the maximum return with a certain risk (Jorion, 2002; 323). The best way to analyze the market for good returns is through portfolio construction (Mohith, et al. 2017). The basic concept in portfolio management is the principle of diversification, whereby diversifying investors can reduce portfolio risk without the need to reduce the expected income on the portfolio (Wiksuana, 2017: 7). Portfolio construction is useful in diversifying risk rather than holding one share (Das \& Agarwal, 2014). Investors will choose * Corresponding author. Tel: +62 0361 - 229119

E-mail address: hennyrahyuda@unud.ac.id (H. Rahyuda) 
portfolios that can provide satisfaction through risk and return. Every investor invests his/her funds in a portfolio to get maximum return with lower risk (Poornima \& Remesh 2016). The optimal portfolio is a portfolio with the best combination of expected returns and risks (Jogiyanto, 2015: 367; Nurhayati \& Endri, 2020).

One of the methods used in determining the investment strategy is the formation of a portfolio, where the type of portfolio used is an active portfolio and a passive portfolio. Passive portfolio strategy includes the actions of managers who tend to be passive in investing in stocks and only base their stock movements on market index movements. This means that investors are not actively seeking information or buying and selling shares that can generate abnormal returns. Active portfolios include active investors' actions in selecting and buying and selling stocks, seeking information, keeping track of stock price movements and times and other active actions to generate abnormal returns. An investor in implementing this strategy must be careful in taking actions related to investment (Jones, 2004; 34). The momentum portfolio is an active portfolio strategy that investors and investment managers can use to improve the performance of their stock portfolios. This strategy is carried out by buying stocks that previously had good performance and selling stocks that previously had poor performance (Polakilan, 2015; Le, 2018; Le, et al., 2018). In this strategy, investors will look for the right momentum or time, when the stock price certainly provides benefits for investors, namely by selling shares. According to Jogiyanto (2013: 337), an efficient portfolio (Efficient Portfolio) is a portfolio that is in a group (set) that is feasible to offer investors maximum return expectations for various levels of risk and minimum risk for various levels of expected returns. Efficient is always seen in terms of cost, then an efficient portfolio is also seen in terms of the most cost-effective of the various portfolios offered, because every investor does not want to invest their funds in places that are considered inefficient. The optimal portfolio is a portfolio with the best combination of risk and expected returns. All optimal portfolios are efficient portfolios. Investors who prefer risk will choose portfolios with high returns by paying higher risk compared to investors who do not like risk (Jogiyanto, 2013: 339). Portfolio performance using risk-adjusted return (a portfolio that includes risk and return) can be measured by the Sharpe index, Treynor index, and Jensen index (Tandelilin, 2010; Nguyen, et al., 2020). Based on research from Pardosi and Wijayanto (2015), there is no significant difference between return and risk in the formation of an optimal portfolio using the Markowitz method, so this encourages research to use the Treynor method. The Treynor ratio is a measure of portfolio performance developed by Jack Treynor, and this ratio is often referred to as the reward to volatility ratio. The difference with the Sharpe ratio is the use of the securities market line as an approximate measure, and not the capital market line as in the Sharpe ratio. The assumption used by Treynor is that the portfolio is well diversified so that the risk that is considered relevant is systematic risk (measured by beta). The Treynor ratio is obtained by dividing the reduction in the average expected return by the risk-free rating by the portfolio beta.

The results of the research according to Zahid (2015) with the Treynor-Black Model show that in portfolio method an optimal portfolio can be formed consisting of nine stocks with the resulting return value better than the market return and Single-Index portfolio return and from the performance evaluation results using the Jensen, Sharpe method, Treynor, Sortino, Information Ratio, T2 and M2, Treynor's portfolio shows good performance because the value of the overall evaluation produces a positive value. The evaluation value of the Treynor index model portfolio is better than the evaluation value of the Single-Index portfolio. The portfolio method using the Treynor index model can form an optimal portfolio with good performance. Compared to the beginning of 2020, the outbreak of the corona virus caused the Indonesian stock market to not be separated from the 'infection' of the coronavirus outbreak, leaving the level of 6,000. JCI fell 4.87 percent from the level of 6,244 to 5,940 in a week. To note, the corona virus first appeared in Wuhan, Hubei Province, China. Meanwhile, the number of cases of the corona virus has spread to 16,600 . This number is more than the victims who contracted the SARS virus in 2003. Even the World Health Organization (WHO) has declared the coronavirus epidemic a global emergency. Not only has an impact on health, but economists also predict the corona virus outbreak will cut China's economic growth by 2 percent in the first quarter of 2020. As a result, the Bamboo Curtain country has the potential to experience economic losses of up to US \$ 62 billion. The LQ45 Index is a complement to the Composite Stock Price Index (IHSG) and provides information for investors in analyzing stock price movements of stocks actively traded on the Indonesia Stock Exchange because 45 stocks listed in LQ45 have liquidity, financial condition, and good growth prospects. and has a high market capitalization and trading frequency. The advantage for companies that are included in the LQ 45 Index is that capital market players have recognized and believed that the company has a good level of liquidity and market capitalization and has good prospects in the future to encourage the increase in share prices in a positive direction (Lutfi \& Hadiprajitno, 2014). The criteria for an issuer to be included in the LQ45 index calculation are to consider factors such as having been listed on the IDX for at least 3 months, transaction activity in the regular market, namely value, volume and frequency of transactions, number of trading days on the regular market, market capitalization in a certain period. as well as the financial condition and growth prospects of the company (Indonesia Stock Exchange, 2010). Entering the early trading period of 2020, the performance of the LQ-45 index is still positive, beating the average share price performance on the Indonesia Stock Exchange (IDX), following investors' buying action of these selected stocks. So far, the performance of the LQ-45 index since the beginning of the year (year to date / ytd) was positive $0.63 \%$ at the level of 1,020 , higher than the performance of the Composite Stock Price Index (JCI) which was corrected $1.05 \%$ to the level of 6,233 at the close of Wednesday. (22/1/2020). In 2019, the performance of the LQ-45 index was able to grow by 3.23\%, also better than the JCI which strengthened only $1.7 \%$. The stock market crash is inevitable due to COVID-19. Many businesses have closed / gone bankrupt, unemployment has increased, poverty has increased, and the feeling of fear has gripped many investors so that 
many investors have sold their shares so that stock prices plummeted all over the world stock exchanges. The Covid-19 pandemic conditions caused stock trading to decline in the first quarter of 2020 compared to 2019.

The number of companies increased in the first quarter in 2020 compared to 2019, but there was a significant decrease in the number of stock transactions in 2020, the decline in these transactions was due to the Covid-19 pandemic. Seeing the decline in the number of stock transactions due to the pandemic and an increase in the number of companies in 2020 , investors must be prepared to face new conditions, which in the future there will be several policies that will be changed and relaxed, including about investing, it is necessary to adapt where investors must rearrange their portfolios which is owned. During the COVID-19 pandemic, investors must be careful about investing in a holistic and diverse portfolio, because stock markets around the world have on average experienced a decline (Collins, 2020). Investors need to build a portfolio of multiple assets that will maximize returns for a certain level of risk. Likewise, with the expected rate of return, an investor can build a portfolio with the lowest possible risk. There are previous studies that analyzed stock returns before and after the occurrence of policies or pandemics, including Pramono (2007) which showed that there were changes in abnormal returns before and after the announcement of the right issue. Likewise, Kurniawati (2006) concluded that the announcement of earnings per share made by companies listed on the Indonesia Stock Exchange received reactions from the market. Meanwhile, research conducted by Suharyanto and Asma, (2013) concluded that there was no difference in abnormal stock returns before and after the announcement of the loan to value kpr regulation. Katti (2018) conducted a study entitled "The Influence of Political Events (Presidential Elections and Cabinet Composition Announcements) on Industrial Sector Shares in the Indonesia Stock Exchange. The purpose of this study is to determine the reactions and differences in abnormal returns of industrial sector stocks on the Indonesia Stock Exchange. (IDX) between before and after political events (presidential elections and announcement of cabinet composition). The sample of this study used a purposive sampling method, the sample in the study was 40 companies. The results of the study can be concluded that there is an abnormal return around national political events, but there is no difference in Average Abnormal Return (AAR) before and after political events. This shows that the predictions and information received by stock market players are relatively the same. Kiky (2020) conducted a study entitled "Risk Management of the 2020 Black Swan Event in Indonesia (Case Study of the Covid-19 Effect)". This research has had many significant impacts on various businesses in Indonesia. This pandemic was first announced by the government in March 2020 and as a result, the Composite Stock Price Index in Indonesia is moving towards a downward trend. The results confirmed that indeed after the announcement, the JCI decreased significantly and lost almost 50\% of its initial value in December 2019. This research also shows that this event cannot be considered a black swan event because the JCI has been moving gradually to decline since February 2020. Anwar (2019) conducted on the effect of political events on Industrial Sector Shares in the Indonesia Stock Exchange.

This study uses 84 sample companies that have been selected through the purposive method for 14 days of the presidential election period, and 14 days of announcements from the cabinet event period. The results show that the presidential election event was able to influence the trading volume of the industrial sector, while the cabinet announcement event showed zero results (no effect at all) on the industrial sector stock trading that occurred on the Indonesia Stock Exchange. Rifa'I et al. (2020) state that there are differences in the Composite Stock Price Index before and after the 2020 Covid-19 Pandemic. Kusnandar and Bintari (2020) state that there is a statistically significant difference in abnormal returns before and after the announcement of changes in trading time on stock exchange transactions. This means that the announcement of the change in trading time on stock exchange transactions carried out by the Indonesia Stock Exchange is a negative signal which can be said to be a bad news announcement, so that investors are more interested in selling their share ownership rather than increasing their share ownership. The existence of a research gap from various previous studies and supported by the state of stocks whose price changes were greatly influenced by the Covid-19 pandemic encouraged researchers to examine stock portfolio analysis in LQ45 stocks. LQ45 shares are used in this study because these stocks are the most liquid stocks compared to others. So that the formulation of the problem that is formed is there a significant difference in the formation of the LQ45 stock portfolio in the first quadrimester 2019 and 2020 ?

\section{Literature Review}

\subsection{Theoretical background}

Portfolio theory states that both risk and return must be considered, assuming a formal framework is available to measure them both in portfolio formation. In its basic form, portfolio theory begins with the assumption that the rate of return on future securities can be estimated and then determines risk by varying the distribution of returns. With certain assumptions, portfolio theory produces a linear relationship between risk and return. Portfolio theory is an investment approach initiated by Harry M. Makowitz who is an economist who graduated from the University of Chicago who won the Nobel Prize in economics in 1990. Portfolio theory is concerned with estimating investors' expectations of risk and return, which are measured statistically to create a portfolio. the investment. Markowitz describes how to combine assets into an efficient portfolio diversification. In this portfolio, risk can be reduced by adding the number of types of assets to the portfolio and the expected return can increase if there are differences in the price movements of the combined assets ("Harry Max Markowitz"). In practice, investors in securities often diversify. in investing by combining various securities, in other words they form a portfolio. 
According to Husnan (2015: 45), a portfolio means a set of investments. This stage involves identifying which securities to choose and what proportion of funds will be invested in each of these securities. The selection of many securities (investors diversify) is intended to reduce the risk borne. The choice of these securities is influenced, among others, by risk preferences, patterns of cash requirements, tax status, and so on. It would be difficult for us to form a portfolio consisting of all investment opportunities, because it is usually used as a proxy consisting of many stocks or market indexes. For example, the Jakarta Stock Exchange uses the Composite Stock Price Index (IHSG) or the LQ45 Index. In the evaluation phase, investors assess the portfolio performance, both in terms of the level of benefits obtained and the risks borne. According to Husnan (2003: 45), it is not true that portfolios that provide higher returns must be better than other portfolios. Portfolio theory states that both risk and return must be considered, assuming a formal framework is available to measure them both in portfolio formation. In its basic form, portfolio theory begins with the assumption that the rate of return on future securities can be estimated and then determines risk by varying the distribution of returns. With certain assumptions, portfolio theory produces a linear relationship between risk and return. Portfolio theory assumes that rational investors refuse to increase risk without an increase in expected returns. The relationship between accepted risk and expected return is the basis for modern lending and investment decisions. The greater the risk on the investment or loan, the greater the rate of return desired to cover that risk. An event study is a study that studies market reactions to an event whose information is published as an announcement (Jogiyanto, 2014). Ball and Brown (1968) and Fama (1970) used the event study methodology as it is widely used today. In the last two decades, event studies have been used to examine events outside of economic issues. Like Chen and Kim (2007) who examined the avian flu outbreak and the Severe Acute Respiratory Syndrome (SARS) outbreak also influenced market reactions in Asian countries. Hapsari (2012) examined the market reaction to terrorist bomb attacks in Indonesia, and Trisnawati (2011) examines the effect of political events (presidential elections) on changes in stock trading volume and stock prices. In conducting an event study, MacKinlay (1997) stated that Ball and Brown and Fama, Fisher, Jensen and Roll carried out five stages as follows: (1) defining the date the market received news; (2) estimate the yield if this news does not exist; (3) measure the difference between the observed yields and the yields if this news does not exist, or measure the abnormal return; (4) calculating the cumulative abnormal returns, and aggregating the cumulative abnormal returns among sectors or companies; (5) statistically testing aggregate returns to determine whether the abnormal returns are significant or not. In the event study, the observation period is divided into two, namely the estimated period and the event period. The estimated period is the period before the event while the event period is the period around the occurrence of the event to be studied. Event study research is classified into four categories (Jogiyanto, 2014: 7), namely Information Content, Event study is used to test the information content of an event. If an event or information contains information, the market will respond, which is indicated by an abnormal return. Market Efficiency, Efficient market testing is a continuation of testing the information content. If the information content test only tests for abnormal returns as a market reaction, the efficient market test continues by testing the reaction speed of the market. The market is called information efficient if an event or information is fully and quickly responded to by the market. Model evaluation, model evaluation is a study that evaluates which model is most suitable for certain conditions. Metric Descriptions, Metric description category research tries to explain the causes of market reactions in a more advanced way.

\subsection{Hypotheses}

Nafia (2018) explained that the optimal portfolio with the Single Index Method consists of seven stocks, while the optimal portfolio using the Markowitz Method consists of five stocks. Based on these two methods, the calculation of the Sharpe Index, Treynor Index and Jensen Index in the Markowitz method has a higher value than the Single Index Method, which makes the optimal portfolio with the Markowitz Method have a better performance. Poornima and Aruna (2015) used the Sharpe's single index model and the efficient frontier Markowitz method with a sample of banking and IT companies in India from January 2010 to December 2015, the results showed that there were three companies selected for portfolio formation, including: Ramco Systems (50\%), Axis Bank (38\%) Bank of Baroda (12\%). Nandan and Srivastava (2017) used a sample of Nifty 50 stocks in the period 1 from August 2010 to July 31, 2015 with the Markowitz efficient frontier method, getting the results that there were 24 stocks that met the optimal portfolio requirements. The largest proportion of shares is held by shares in the banking and pharmaceutical sectors. Rifa'I et al. (2020) stated that there are differences in the Composite Stock Price Index before and after the 2020 Covid-19 Pandemic. Systematic risk is smaller than unsystematic risk if investors use portfolio diversification. Kusnandar and Bintari (2020) stated that there is a statistically significant difference in abnormal returns before and after the announcement of changes in trading time on stock exchange transactions. Andriyani, et al. (2016) stated that there is no significant difference between the optimal portfolio and the return and risk of individual stocks that form optimal portfolios using the constant correlation model and stochastic dominance methods.

\section{$\mathbf{H}_{1}$ : There is a significant difference between the optimal portfolio using the LQ45 quadrimester I 2019 stock treynor index model against the 2020 I quadrimester.}

\section{Research Methods}

This study compares the use of the treynor index model to form the optimal stock portfolio from LQ45. The results of the study can be used as a guideline for making stock portfolios from making investment decisions during the corona pandemic. The population in this study is the stocks listed in LQ45. The formation of this optimal stock portfolio is carried out on 
stocks that are included in LQ45 quadrimester I in 2019 and compared to Quadrimester 1 in 2020 which is the closing price of each month obtained from the Indonesia Stock Exchange (IDX) website, www.idx.co. id and www.finance.yahoo.com. Analysis of optimal portfolio performance is carried out for stocks including LQ45.The technical analysis used in determining the performance of the stock portfolio with a single index and measuring performance using the Treynor index.

In this study using quantitative analysis of available stock price data, this study uses the Treynor Index Model and $t$ Test to compare the performance of shares per sector. Optimal portfolio performance analysis is carried out for each of the primary, secondary, and tertiary sectors. The technical analysis used in determining the performance of the stock portfolio with the Single Index and measuring performance using the Treynor index in this study are as follows (Hartono, 2010):

1) Calculate the level of stock returns and expected return

$R i=\frac{P_{t}-P_{t-1}}{P_{t-1}}$

$E\left(R_{i}\right)=\alpha_{i}+\beta_{i} * E\left(R_{m}\right)$

2) Calculate the index of market returns, alpha and beta

$R_{m}=\frac{I H S G_{t}-I H S G_{t-1}}{I H S G_{t-1}}$

$\alpha_{i}=E\left(R_{i}\right)-\beta_{i} * E\left(R_{m}\right)$

$\beta_{i}=\frac{\sigma_{i m}}{\sigma_{m}^{2}}$

3) Calculate stock risk $\left(R_{i}\right)$ and market risk $\left(R_{m}\right)$

$\operatorname{Var}\left(R_{i}\right)=\sum_{j=i}^{n}\left(\left[R_{i j}-E\left(R_{i}\right)\right]^{2} * p_{j}\right)$

standar deviasi $(\sigma)=\sqrt{\operatorname{Var}\left(R_{i}\right)}$

$\operatorname{Var}\left(R_{m}\right)=\sum_{j}^{n}\left(\left[R_{i j}-E\left(R_{i}\right)\right]^{2} * p_{j}\right)$

standar deviasi $(\sigma)=\sqrt{\operatorname{Var}\left(R_{m}\right)}$

4) Residual or risk variants are not systematic ${\sigma_{i}}^{2}={\beta_{i}}^{2} *{\sigma_{m}}^{2}+{\sigma_{e i}}^{2}$

5) Calculate excess return to beta

$E R B_{i}=\frac{E\left(R_{i}\right)-R_{B R}}{\beta_{i}}$

6) Calculate cut off-point (C*)

$A_{j}=\frac{\left[E\left(R_{i}\right)-R_{B R}\right] * \beta_{i}}{\sigma_{e i}^{2}}$

$B_{i}=\frac{B_{i}^{2}}{\sigma_{e i}^{2}}$

$C_{i}=\frac{\sigma_{m}^{2} \sum_{j=1}^{i} A_{j}}{1+\sigma_{m}^{2} \sum_{j=1}^{i} B_{j}}$

7) Calculate the proportion of each share

$W_{i}=\frac{Z_{i}}{\sum_{i=1}^{k} Z_{i}}$

$Z_{i}=\frac{\beta_{i}}{\sigma_{e i}{ }^{2}}\left(E R B_{i}-C^{*}\right)$

8) Calculate the portfolio, portfolio alpha and portfolio beta $E\left(R_{p}\right)=\alpha_{\rho}+\beta_{\rho} * E\left(R_{m}\right)$

$\alpha_{\rho}=\sum_{i=1}^{n} W_{i} * \alpha_{i}$ 
$\beta_{\rho}=\sum_{i=1}^{n} W_{i} * \beta_{i}$

9) Calculate portfolio risk

${\sigma_{p}}^{2}=\beta_{p}^{2} * \sigma_{m}^{2}+\sum_{i=1}^{n} W_{i}^{2} * \sigma_{e i}^{2}$

10) Calculate the performance of the stock portfolio using the Treynor index

$\widehat{T}_{P}=\frac{\bar{R}_{P}-\overline{R F}}{\hat{\beta}_{P}}$

After obtaining the results of the stock portfolio performance in each of the primary, secondary, and tertiary sectors, then to test the hypothesis using the Independent T-Test Sample Test

\section{Results and Discussion}

Based on the treynor index calculation that has been carried out on LQ45 shares in Quadrimester I Year 2019 and it is attached to Appendix 1, companies with the EXCL code during January to April occupied the highest position in the optimal number of share purchases in the portfolio. Based on the treynor index calculation that has been carried out on LQ45 shares in the first quadrimester of 2020, the optimal number of purchases with the highest percentage is occupied by companies with the BRPT code of 38.5 percent in January. In February, it was occupied by companies with the ADHI code of 50.6 percent. In March it was occupied by a company with the SRIL code of 13.4 percent and in April it was occupied by KLBF of 95.3 percent, this is because during the first three months of 2020 amid the Covid-19 pandemic, KLBF recorded net sales of up to Rp 5.8 trillion. This number grew by $8.01 \%$ compared to the same period in the previous year which amounted to Rp 5.37 trillion, the increase in sales in the first quarter of 2020 came from the distribution and logistics segment which increased by $13.21 \%$ year on year (YoY) to Rp 1.8 trillion (www.invest.kontan.co.id). The health sector, such as the pharmaceutical company Kalbe Farma, is a good choice during the Covid-19 pandemic because medicines are very much needed by the community today. Based on the results of Table 1, the average return value in the first quadrimester in 2019 is $83.32 \%$ and in 2020 is $139.18 \%$. Portfolio beta is a systematic risk measure of a stock, so that in the first quadrimester of 2019 it was 5,407 and in 2020 it was 7,406. Risk free is a risk-free investment as seen from the Bank Indonesia Certificate (SBI), so that the Treynor index value is obtained as shown in Table 1.

Table 1

T Test Results on LQ 45 Quadrimester 1 Shares in 2019 and 2020

\begin{tabular}{cccccc}
\hline & Year & N & Mean & Std. Deviation & Std. Error Mean \\
\hline \multirow{2}{*}{ Treynor } & 2019 & 4 & 0.155 & 0.027 & 0.013 \\
& 2020 & 4 & 0.233 & 0.473 & 0.236 \\
\hline
\end{tabular}

Table 2

Independent Samples Test

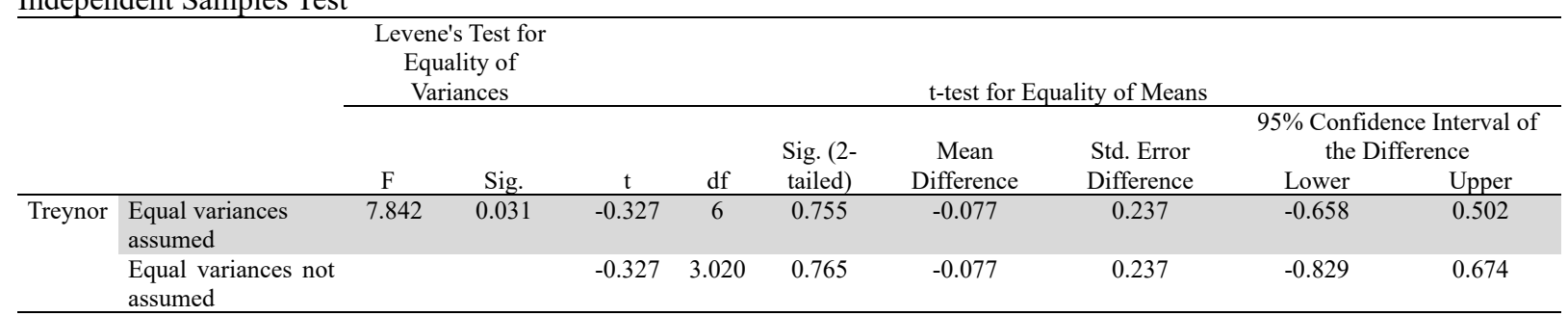

Based on the results of the analysis, the $t$ value is -0.327 with a significance level of $0.031<0.050$, so Ho is rejected and $\mathrm{H} 1$ is accepted, so there is a significant difference in the optimal portfolio using the treynor index model when the momentum of Covid-19 in the same period is in the LQ45 index. This is due to the covid-19 outbreak which caused business actors and economic movements to weaken, this triggered a decline in the value of shares on the LQ45 stock index. This is also based on the momentum theory. This theory says that the momentum portfolio is one of the active portfolio strategies that investors and investment managers can use to improve the performance of their stock portfolios. This strategy is carried out by buying stocks that previously had good performance and selling stocks that previously had poor performance (Polakilan, 2015). In this strategy, investors will look for the right momentum or time, when the stock price certainly provides benefits for investors, namely by selling shares. This study supports previous research, namely research conducted by Sirait et al. (2012) showing that there is a significant difference in the average abnormal return before and after the event. Nurhaeni (2009) shows that there is a significant difference in the average stock trading volume activity before and after the event. Sari, et 
al. (2017) state that there is a significant difference in the average trading volume before and after the 2016 US presidential election. Rifa'I et al. (2020) state that there are differences in the Composite Stock Price Index before and after the Covid19 Pandemic year. 2020. Kusnandar and Bintari (2020) state that there is a statistically significant difference in abnormal returns before and after the announcement of changes in trading time on exchange transactions. In accordance with the optimal portfolio theory where investments are advised to buy shares in a variety of different stocks which is called diversification, this applies to the first quadrimester of 2020 in general. In the first three months, namely January, February, and March, the shares purchased were diversified, but at the end of the Quadrimester, namely April, the shares purchased were generally not diversified. In April 2020, almost all the recommended portfolio percentages were dominated by one share, namely KLBF, so there was no diversification. KLBF shares are the stock code of the Kalbe Farma Company, which is engaged in the health sector, especially pharmaceuticals. In accordance with an event study, the Covid-19 pandemic during this research period caused a decline in performance in almost all existing sectors. However, there are several sectors that did not experience a decline and instead increased, namely the health sector. This is because the public prefers not to make purchases that are not needed and use the funds for health problems such as at community events buying masks, hand sanitizers, common fever medicines such as paracetamol and so on. This is what makes one of the largest pharmaceutical companies in Indonesia, namely Kalbe Farma (KLBF), has soaring value that it is recommended to be used as a stock portfolio.

\section{Conclusions and Suggestion}

Based on the results of this discussion, the conclusion of this study is that there is a significant difference in the optimal portfolio using the Treynor index model between the 2019 and 2020 quadrimester I on LQ45 stocks, this is influenced by conditions amid the Covid-19 pandemic which affects all sectors. The highest optimal number of purchases in April 2020 is occupied by companies with the KLBF code, this is an advantage that the company gets during the Covid-19 pandemic. The health sector, such as the pharmaceutical company Kalbe Farma, is a good choice during the Covid-19 pandemic because medicines are very much needed by the community today. Based on the discussion of the results of the research and the conclusions drawn, some suggestions for investors can be made, namely that the investor is expected to be able to estimate in advance the stocks that will be selected for investment. This is very important because it will affect the allocation of funds to each company that is in every share in LQ45. Allocating funds according to the right calculations will allow these investors to get optimal returns on each existing share, even during the Covid-19 pandemic. Further researchers are advised to use different variations, by using different variations of research time and selecting sectors to be used with various available models such as CAPM, and other single index models such as the Markowitz index and the Jensen index. Future research can use existing stock exchanges in other countries. This study has limitations, namely that it only uses one type of research index model, namely the Treynor index without using other indices such as the Markowitz index or the Jensen index as a comparison of portfolio values, and this study only compares quadrimester I in 2019 and 2020.

\section{References}

Andriyani, L., Farida, F., \& Machfiroh, D. L. (2016). Analisis Komparatif Pembentukan Portofolio Optimal Menggunakan Capital Asset Pricing Model (Capm) Dan Stochastic Dominance. Jurnal Analisis Bisnis Ekonomi, 14(1), 19-33.

Anwar. (2019). Pengaruh Peristiwa Politik Tahun 2019 (Pemilu Presiden dan Pengumuman Susunan Kabinet) Terhadap Saham Sektor Industri Di Bursa Efek Indonesia. Skripsi Universitas Islam Malang.

Astuti, D., \& Toto, S. (2005). Analisis Pembentukan Portofolio Optimal Pada Perusahaan Industri Plastic Dan Packaging Yang Terdaftar Di Bursa Efek Jakarta Studi Kasus (1999-2003). Proceeding, Seminar Nasional PESAT, Auditorium Universitas Gunadarma, Jakarta.

Ball, R., \& Brown, P. (1968). An Empirical Evaluation of Accounting Income Numbers, Journal of Accounting Research, $6(2), 159-178$.

Chen, M.-H., Jang, S., \& Kim, W. G. (2007). The impact of the SARS outbreak on Taiwanese hotel stock performance: An event-study approach. International Journal of Hospitality Management, 26(1).

Collins, C. N. (2020). Effect of COVID-19 Pandemic on Global Stock Market Values: A Differential Analysis. Acta Universitatis Danubius (Economica), 16(2).

Das, S., \& Ankit A. (2014). Construction of Optimal Portfolio Of Banking Stocks-A Diversification Strategy. International Journal of Financial Management (IJFM), 1-6.

Fahmi, I. (2013). Pengantar Pasar Modal. Bandung: Alfabeta.

Fama, E. (1970). Efficient Capital Markets - A review of theory and empirical work. Journal of Finance, 25(2).

Hartono, J. (2013). Teori Portofolio dan Analisis Investasi. Yogyakarta,: BPFE Yogyakarta.

Hapsari, E., I. (2012). Kekuatan Rasio Keuangan dlam Memprediksi Kondisi Financial Distress Perusahaan Manufaktur yang terdaftar di BEI. Jurnal Dinamika Akuntansi.

Husnan, S. (2015). Dasar-Dasar Teori Portofolio dan Analisis Sekuritas (Edisi 5). Yogyakarta : UPPN STIM YKPN.

Jogiyanto. (2014). Teori Portofolio dan Analisis Investasi. Edisi Kesembilan. Yogyakarta: Penerbit BPFE.

Jones, C. (2004). Investment. New York: Prentice-Hall

Jorion, P. (2002). Value at Risk. Singapura: McGraw Hill. 
Katti, S., W., B. (2018). Pengaruh Peristiwa Politik (Pemilu Presiden dan Pengumuman Susunan Kabinet) Terhadap Saham Sektor Industri Di Bursa Efek Indonesia. Skripsi Univesitas Merdeka Madiun. 1(1).

Kiky, A. (2020). Manajemen Resiko Terhadap Black Swan Event 2020 di Indonesia (Studi Kasus Efek Covid-19). Jurnal Bina Manajemen, 8(2), 90-105

Kurniawati, I. (2006). Analisis Pengaruh Pengumuman Earning terhadap Abnormal Return dan Tingkat Likuiditas Saham : Analisis Empiris pada Nonsynchronous Trading. JAAI, 10(2), 173- 183.

Kusnandar, D., \& Bintari, V. (2020). Perbandingan Abnormal Return Saham Sebelum dan Sesudah Perubahan Waktu Perdagangan Selama Pandemi Covid-19. Jurnal Pasar Modal Dan Bisnis, 2(2), $195-202$. https://doi.org/10.37194/jpmb.v2i2.49

Le, T. P. (2018). Jensen's alpha estimation models in Capital Asset Pricing Model. Journal of Asian Finance, Economics and Business, 5(3), 19-29. https://doi.org/10.13106/jafeb.2018.vol5.no3.19

Le, T. P., Kim, S. K., \& Su, Y. (2018). Re-examination of estimating beta coefficient as a risk measure in CAPM. Journal of Asian Finance, Economics and Business, 5(1), 11-16. https://doi.org/10.13106/jafeb.2018.vol5.no1.11

MacKinlay, A., C. (1997). Event Studies in Economics and Finance. Journal of Economic Literature, 15(March),13-39.

Mohith, S., Pavithra, S., Bharadwaj, R., \& Ananth, A. (2017). Application of Single Sharpe index on the optimum portfolio construction in Indian Capital Market. International Journal of Physical and Social Sciences, 7(7), 60-72.

Nandan, T., \& Srivastava, N. (2017). Construction of Optimal Portfolio Using Sharpe's Single Index Model: An Empirical Study on Nifty 50 Stocks. Journal of Management Research and Analysis, 4(2), 74-83.

Nguyen, N., Nguyen, T., Tran, T., \& Mai, N. (2020). Shrinkage Model Selection for Portfolio Optimization on Vietnam Stock Market. The Journal of Asian Finance, Economics and Business, 7(9), 135-145. https://doi.org/10.13106/jafeb.2020.vol7.no9.135

Nurhaeni, N. (2009). Dampak Pemilihan Umum Legislatif Indonesia Tahun 2009 Terhadap Abnormal Return dan Aktivitas Volume Perdagangan Saham di BEI. Tesis. Universitas Diponegoro, Semarang.

Nurhayati, I., \& Endri, E. (2020). A New Measure of Asset Pricing: Friction-Adjusted Three Factor Model. Journal of Asian Finance, Economics and Business, 7(12), 605-613. https://doi.org/10.13106/jafeb.2020.vol7.no12.605.

Pardosi, B., \& Wijayanto, A. (2015). Analisis Perbedaan Return dan Risiko Saham Portofolio Optimal Dengan Bukan Portofolio Optimal. Management Analysis Journal, 4(1), 1-10.

Polakitan, C., D. (2015). Analisis Komparasi Risiko Saham LQ 45 dan Non LQ 45 Pada Beberapa Sub Sektor Perusahaan Yang Terdaftar Di Bursa Efek Indonesia (BEI). Jurnal Riset Bisnis dan Manajemen, 3(1).

Poornima, S, \& Aruna P. R. (2016). Construction of Optimal Portfolio using Sharpe's Single Index Model: A Study with Reference to Automobiles and Pharmaceutical Sector. International Journal of Advance Research in Computer Science and Management Studies, 159-163.

Pramono, Y. W. (2007). Analisis Abnormal Return Saham Dan Volume Perdagangan Saham Harian Sebelum Dan Sesudah Pengumuman Right Issue. Repository Universitas Snata Dharma.

Rifa'i, M., Hasan, Junaidi, Arista, F., K., S. (2020). Pengaruh Peristiwa Pandemi Covid-19 Terhadap Indeks Harga Saham Gabungan. Jurnal Ilmiah Riset Akuntansi, 9(06)

Sari, N. P. T. P, Purnamawati, I., G., A., \& Herawati, N., T. (2017). Analisis Komparatif Saham Lq45 Sebelum Dan Sesudah Pilpres Amerika Serikat 2016. e-Journal S1 Ak Universitas Pendidikan Ganesha, 7(1)

Sirait,R., S., Wiwik, T., and Fitrini, M. (2012). Dampak Pergantian Menteri Keuangan RI Tahun 2010 Terhadap Abnormal Return Perusahaan Perbankan yang Terdaftar di BEI. E-jurnal BINAR Akuntansi, 1(1), 14-22

Suharyanto, D., and Asma, R. (2013). Analisis Abnormal Return Saham Sebelum dan Sesudah Pengumuman Peraturan Loan To Value KPR (Studi Pada Perusahaan Properti Di Bursa Efek Indonesia). Jurnal Wawasan Manajemen, 1(2), 281-298

Tandelilin, E. (2010). Portofolio dan Investasi. Yogyakarta: Kanisius

Trisnawati, F. (2011). Pengaruh Peristiwa Politik Terhadap Perubahan Harga Saham. Pekbis Jurnal, 3(3), 528-535 


\section{Appendixes}

Appendix 1

Calculation of Treynor Index in Quadrimester I Year 2019

\begin{tabular}{|c|c|c|c|c|c|c|c|}
\hline \multicolumn{2}{|c|}{ Jan } & \multicolumn{2}{|c|}{ Feb } & \multicolumn{2}{|c|}{ Mar } & \multicolumn{2}{|c|}{ Apr } \\
\hline Company Code & $\begin{array}{l}\text { Purchase } \\
\text { Amount }\end{array}$ & Company Code & $\begin{array}{l}\text { Purchase } \\
\text { Amount }\end{array}$ & Company Code & $\begin{array}{l}\text { Purchase } \\
\text { Amount }\end{array}$ & Company Code & $\begin{array}{l}\text { Purchase } \\
\text { Amount }\end{array}$ \\
\hline ADRO & $0.6 \%$ & ADHI & $0.9 \%$ & ADHI & $0.6 \%$ & ASII & $1.2 \%$ \\
\hline AKRA & $8.5 \%$ & AKRA & $0.8 \%$ & BBNI & $8.0 \%$ & BBRI & $13.6 \%$ \\
\hline BBCA & $2.0 \%$ & BJBR & $10.3 \%$ & BBRI & $10.9 \%$ & BBTN & $0.4 \%$ \\
\hline BBRI & $4.2 \%$ & BKSL & $10.4 \%$ & BKSL & $0.1 \%$ & BJBR & $0.8 \%$ \\
\hline BBTN & $2.7 \%$ & BRPT & $9.9 \%$ & BMRI & $0.1 \%$ & BKSL & $0.1 \%$ \\
\hline BKSL & $0.1 \%$ & ELSA & $10.2 \%$ & BSDE & $0.9 \%$ & EXCL & $28.0 \%$ \\
\hline BRPT & $0.4 \%$ & EXCL & $14.5 \%$ & EXCL & $31.7 \%$ & ICBP & $1.3 \%$ \\
\hline BSDE & $0.5 \%$ & JSMR & $1.1 \%$ & INTP & $15.1 \%$ & INDF & $1.6 \%$ \\
\hline ELSA & $0.1 \%$ & LPKR & $10.3 \%$ & ITMG & $1.9 \%$ & MEDC & $7.3 \%$ \\
\hline EXCL & $16.7 \%$ & $\mathrm{MNCN}$ & $10.7 \%$ & JSMR & $7.2 \%$ & PTBA & $5.9 \%$ \\
\hline INCO & $6.9 \%$ & PGAS & $10.5 \%$ & PGAS & $0.8 \%$ & PTPP & $0.1 \%$ \\
\hline INDF & $0.1 \%$ & SRIL & $0.2 \%$ & PTBA & $0.2 \%$ & SCMA & $5.2 \%$ \\
\hline INDY & $6.3 \%$ & SSMS & $10.2 \%$ & РТРP & $1.4 \%$ & WIKA & $11.9 \%$ \\
\hline INKP & $3.5 \%$ & & $100.0 \%$ & SMGR & $5.4 \%$ & WSBP & $20.2 \%$ \\
\hline INTP & $0.9 \%$ & & & WIKA & $14.4 \%$ & WSKT & $2.3 \%$ \\
\hline ITMG & $1.6 \%$ & & & WSBP & $0.5 \%$ & & $100.0 \%$ \\
\hline JSMR & $5.9 \%$ & & & WSKT & $1.0 \%$ & & \\
\hline KLBF & $2.1 \%$ & & & & $100.0 \%$ & & \\
\hline LPKR & $0.0 \%$ & & & & & & \\
\hline LPPF & $2.6 \%$ & & & & & & \\
\hline MEDC & $6.8 \%$ & & & & & & \\
\hline MNCN & $1.4 \%$ & & & & & & \\
\hline PGAS & $4.9 \%$ & & & & & & \\
\hline PTPP & $3.6 \%$ & & & & & & \\
\hline SMGR & $4.1 \%$ & & & & & & \\
\hline TLKM & $0.1 \%$ & & & & & & \\
\hline UNVR & $2.0 \%$ & & & & & & \\
\hline WIKA & $7.0 \%$ & & & & & & \\
\hline WSKT & $4.4 \%$ & & & & & & \\
\hline & $100.0 \%$ & & & & & & \\
\hline
\end{tabular}

Note: Processed Data

\section{Appendix 2}

Treynor Index Calculation for Quadrimester I Year 2020

\begin{tabular}{|c|c|c|c|c|c|c|c|}
\hline \multicolumn{2}{|c|}{ Jan } & \multicolumn{2}{|c|}{ Feb } & \multicolumn{2}{|c|}{ Mar } & \multicolumn{2}{|c|}{ Apr } \\
\hline Company Code & $\begin{array}{l}\text { Purchase } \\
\text { Amount }\end{array}$ & Company Code & $\begin{array}{c}\text { Purchase } \\
\text { Amount }\end{array}$ & Company Code & $\begin{array}{l}\text { Purchase } \\
\text { Amount }\end{array}$ & Company Code & $\begin{array}{l}\text { Purchase } \\
\text { Amount }\end{array}$ \\
\hline BBNI & $8.7 \%$ & ADHI & $50.6 \%$ & ADHI & $0.8 \%$ & ADHI & $3.0 \%$ \\
\hline BMRI & $31.8 \%$ & AKRA & $0.6 \%$ & ADRO & $0.4 \%$ & ADRO & $0.2 \%$ \\
\hline BRPT & $38.5 \%$ & BBCA & $0.8 \%$ & AKRA & $0.0 \%$ & AKRA & $0.3 \%$ \\
\hline GGRM & $16.5 \%$ & BBNI & $2.4 \%$ & ANTM & $4.2 \%$ & ASII & $0.0 \%$ \\
\hline \multirow[t]{34}{*}{ ICBP } & $4.4 \%$ & BBRI & $4.0 \%$ & ASII & $2.1 \%$ & BBNI & $0.1 \%$ \\
\hline & $100.0 \%$ & BJBR & $0.4 \%$ & $\mathrm{BBCA}$ & $0.2 \%$ & HMSP & $0.3 \%$ \\
\hline & & BSDE & $0.3 \%$ & BBRI & $0.3 \%$ & INDY & $0.1 \%$ \\
\hline & & HMSP & $0.0 \%$ & BBTN & $8.4 \%$ & KLBF & $95.3 \%$ \\
\hline & & INCO & $1.6 \%$ & BJBR & $0.3 \%$ & SCMA & $0.1 \%$ \\
\hline & & INDY & $0.3 \%$ & BKSL & $4.7 \%$ & SMGR & $0.1 \%$ \\
\hline & & ITMG & $16.5 \%$ & BSDE & $0.1 \%$ & SSMS & $0.5 \%$ \\
\hline & & KLBF & $1.3 \%$ & ELSA & $5.1 \%$ & & $100.0 \%$ \\
\hline & & LPPF & $4.7 \%$ & EXCL & $6.9 \%$ & & \\
\hline & & MEDC & $0.5 \%$ & HMSP & $1.7 \%$ & & \\
\hline & & PGAS & $14.9 \%$ & INCO & $0.0 \%$ & & \\
\hline & & SCMA & $0.6 \%$ & INDF & $5.1 \%$ & & \\
\hline & & SMGR & $0.2 \%$ & INDY & $0.0 \%$ & & \\
\hline & & SSMS & $0.3 \%$ & INKP & $4.2 \%$ & & \\
\hline & & & $100.0 \%$ & INTP & $1.6 \%$ & & \\
\hline & & & & ITMG & $0.1 \%$ & & \\
\hline & & & & JSMR & $2.3 \%$ & & \\
\hline & & & & KLBF & $4.1 \%$ & & \\
\hline & & & & LPKR & $0.4 \%$ & & \\
\hline & & & & LPPF & $0.5 \%$ & & \\
\hline & & & & MEDC & $0.0 \%$ & & \\
\hline & & & & $\mathrm{MNCN}$ & $8.0 \%$ & & \\
\hline & & & & PGAS & $0.0 \%$ & & \\
\hline & & & & PTBA & $4.0 \%$ & & \\
\hline & & & & PTPP & $3.8 \%$ & & \\
\hline & & & & SCMA & $0.0 \%$ & & \\
\hline & & & & SRIL & $13.4 \%$ & & \\
\hline & & & & SSMS & $0.0 \%$ & & \\
\hline & & & & TLKM & $4.3 \%$ & & \\
\hline & & & & TPIA & $3.7 \%$ & & \\
\hline & & & & UNTR & $1.2 \%$ & & \\
\hline & & & & WSBP & $3.9 \%$ & & \\
\hline & & & & WSKT & $4.0 \%$ & & \\
\hline & & & & & $100.0 \%$ & & \\
\hline
\end{tabular}


Appendix 3

2019 and 2020 Treynor Quadrimester Index Calculation Results

\begin{tabular}{ccccccccc}
\hline Year & \multicolumn{2}{c}{2019} & \multicolumn{3}{c}{2020} \\
\hline \multirow{2}{*}{ Month } & $\begin{array}{c}\text { Average } \\
\text { Return (\%) }\end{array}$ & $\begin{array}{c}\text { Beta } \\
\text { Portfolio }\end{array}$ & $\begin{array}{c}\text { Risk Free } \\
(\%)\end{array}$ & $\begin{array}{c}\text { Treynor } \\
\text { Index }\end{array}$ & $\begin{array}{c}\text { Average } \\
\text { Return (\%) }\end{array}$ & $\begin{array}{c}\text { Beta } \\
\text { Portfolio }\end{array}$ & $\begin{array}{c}\text { Risk } \\
\text { Free }(\%)\end{array}$ & $\begin{array}{c}\text { Treynor } \\
\text { Index }\end{array}$ \\
\hline Jan & 2.86 & 3.531 & 0.41667 & 0.007 & 14.58 & 1.054 & 0.50 & 0.134 \\
Feb & 347.23 & 3.679 & 0.39583 & 0.943 & 522.93 & 27.336 & 0.50 & 0.191 \\
Mar & -28.10 & 8.161 & 0.37500 & -0.035 & 9.68 & 0.561 & 0.50 & 0.163 \\
Apr & 11.30 & 6.257 & 0.37500 & 0.017 & 9.53 & 0.674 & 0.50 & 0.134 \\
Total & 333.30 & 21.628 & 1.56250 & 0.932 & 556.72 & 29.625 & 2.00 & 0.622 \\
Average & 83.32 & 5.407 & 0.39063 & 0.233 & 139.18 & 7.406 & 0.50 & 0.156 \\
\hline
\end{tabular}

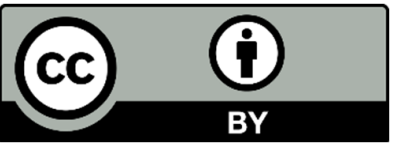

(C) 2022 by the authors; licensee Growing Science, Canada. This is an open access article distributed under the terms and conditions of the Creative Commons Attribution (CC-BY) license (http://creativecommons.org/licenses/by/4.0/). 